\title{
Importance of CRF Receptor-Mediated Mechanisms of the Bed Nucleus of the Stria Terminalis in the Processing of Anxiety and Pain
}

\author{
Lee Tran', Jay Schulkin ${ }^{2}$ and Beverley Greenwood-Van Meerveld*, 1,3,4 \\ 'Oklahoma Center for Neuroscience, University of Oklahoma Health Science Center, Oklahoma City, OK, USA; '2Department of Neuroscience, \\ Georgetown University, Washington, DC, USA; ${ }^{3}$ Department of Physiology, University of Oklahoma Health Science Center, Oklahoma City, OK, \\ USA; ${ }^{4}$ VA Medical Center, Oklahoma City, OK, USA
}

\begin{abstract}
Corticotropin-releasing factor (CRF)-mediated mechanisms in the bed nucleus of the stria terminalis (BNST) have a pivotal role in stressinduced anxiety and hyperalgesia. Although $C R F$ is known to activate two receptor subtypes, $\mathrm{CRF}_{1}$ and $\mathrm{CRF}_{2}$, attempts to delineate the specific role of each subtype in modulating anxiety and nociception have been inconsistent. Here we test the hypothesis that CRF, and $\mathrm{CRF}_{2}$ receptor activation in the anteriolateral BNST (BNST $\mathrm{AL}_{\mathrm{L}}$ ) facilitates divergent mechanisms modulating comorbid anxiety and hyperalgesia. Microinfusions of the specific antagonists CP376395 and Astressin ${ }_{2} B$ into the BNST $A$ L were used to investigate CRF $_{\text {I }}$ and $\mathrm{CRF}_{2}$ receptor functions, respectively. We found that $C R F_{1}$ and $\mathrm{CRF}_{2}$ receptors in the $\mathrm{BNST}_{\mathrm{AL}}$ had opposing effects on exploratory behavior in the elevated plus-maze, somatic mechanical threshold, and the autonomic and endocrine response to stress. However, CRF, or $\mathrm{CRF}_{2}$ receptor antagonism in the $\mathrm{BNST}_{\mathrm{AL}}$ revealed complementary roles in facilitating the acoustic startle and visceromotor reflexes. Our results suggest that the net effect of $\mathrm{CRF}_{1}$ and $\mathrm{CRF}_{2}$ receptor activation in the $\mathrm{BNST}_{\mathrm{AL}}$ is pathway-dependent and provides important insight into the CRF receptor-associated circuitry that likely underpins stress-induced pathologies. Neuropsychopharmacology (2014) 39, 2633-2645; doi:I0.1038/npp.20I4.II7; published online I8 June 2014
\end{abstract}

\section{INTRODUCTION}

Corticotropin-releasing factor $(\mathrm{CRF})$ is a neuromodulator involved in the behavioral and physiological response to stress and is often linked to adversity associated with anxiety and pain disorders, including irritable bowel syndrome (IBS; Chang et al, 2009; Dinan et al, 2006; Fukudo, 2013). In support, our previous studies and others have investigated the effects of repeated psychological stress in a preclinical model that reproduces the hallmark traits of IBS (Bradesi et al, 2005; Myers and Greenwood-Van Meerveld, 2012; Tran et al, 2013; Venkova et al, 2010). The pivotal finding from these studies indicated that the central mechanisms mediating the stress-induced phenotypes following chronic intermittent psychological stress involved increased CRF, particularly in limbic brain regions (Myers and Greenwood-Van Meerveld, 2012; Tran et al, 2013).

Limbic brain regions of IBS patients, including the amygdala and extended amygdala, exhibit hyperactivity in

\footnotetext{
*Correspondence: Dr B Greenwood-Van Meerveld, Oklahoma Center for Neuroscience, VA Medical Center, Oklahoma University Health Sciences Center, Research Administration Room I5IG, 92 I NE 13th Street, Oklahoma City, OK 73I04, USA, Tel: +405 4563547 , Fax: +405456 1719, E-mail: Beverley-Greenwood@ouhsc.edu Received 16 February 2014; revised 16 May 2014; accepted 16 May 2014; accepted article preview online 23 May 2014
}

response to stress, negative effect, and colorectal stimuli when compared with controls (Berman et al, 2008; Bonaz et al, 2002). Interestingly, when IBS patients were challenged with vascular infusions of CRF, there was a greater activation of the extended amygdala in response to colorectal stimuli, suggesting an important role for CRF-mediated mechanisms in the extended amygdala in IBS pathophysiology (Tanaka et al, 2011). Although the cause of CRF hypersensitivity in the extended amygdala is unclear, evidence suggests that hyperexcitability of limbic circuitry can be the result of repeated neural stimulation (Rosen and Schulkin, 1998).

Preclinical studies have reported that persistent elevations of systemic corticosteroids (CORT), such as in chronic stress conditions, upregulate CRF in the amygdala (Makino et al, 1994; Myers et al, 2005; Schulkin et al, 1998; Shepard et al, 2000, 2003; Tran and Greenwood-Van Meerveld, 2012a) as well as the extended amygdala, specifically the bed nucleus of the stria terminalis (BNST; Makino et al, 1994; Shepard et al, 2003; Watts and Sanchez-Watts, 1995). Moreover, our previous study demonstrated that the central amygdaloid nucleus (CeA) has a pivotal role in somatic and colonic nociception, through a descending pathway involving the anteriolateral $\mathrm{BNST}$ (BNST $\mathrm{BL}_{\mathrm{AL}}$; Tran et al, 2012c). However, the precise mechanisms of $\mathrm{CRF}$ in the $\mathrm{BNST}_{\mathrm{AL}}$ regulating comorbid anxiety and hyperalgesia in response to a chronic stressor are unclear. Therefore, the goals of the 
present study were to (i) test the hypothesis that chronic intermittent psychological stress induces anxiety and hyperalgesia through sensitized CRF signaling in the $\mathrm{BNST}_{\mathrm{AL}}$ and (ii) delineate the receptor-mediated mechanisms contributing to CRF sensitization of the $\mathrm{BNST}_{\mathrm{AL}}$.

\section{MATERIALS AND METHODS}

\section{Animals}

Experiments were performed on male Fischer-344 rats, weighing 240-260 g (Charles Rivers Laboratory, Wilmington, MA). All animals were single-housed to prevent postsurgery complications and maintained on a 12-h light/dark cycle (lights on at 0530 hours) at $21^{\circ} \mathrm{C}$ and $70 \%$ humidity with ad libitum access to food and water. Rats were acclimated to the animal facility for 1 week and to the experimenter and the laboratory for an additional week before experimentation. The experiments were approved by the Oklahoma City Veterans Affairs Medical Center Animal Care and Use Committee (IACUC; protocol no. 0807-004) in accordance with standards established by the Guide for Care and Use of Laboratory Animals (1996). All experiments were carried out in accordance with the International Association for the Study of Pain-recommended guidelines of the study of pain.

\section{Stereotaxic Surgeries}

Stereotaxic bilateral implantation of cannulae into the $\mathrm{BNST}_{\mathrm{AL}}$ was performed as previously described (Tran et al, 2012c). Briefly, animals were anesthetized with a ketamine $(100 \mathrm{mg} / \mathrm{kg}$ i.p. $) / x y l a z i n e ~(10 \mathrm{mg} / \mathrm{kg}$ i.p.) and body temperature was maintained at $37^{\circ} \mathrm{C}$ with a homeothermic heating blanket (Harvard Apparatus, Ealing, UK). Rats were placed securely in a stereotaxic surgical frame (Kopf, Tujunga, CA) and a midline incision was made above the skull to expose bregma and lamda. Small holes were made in the skull $-0.24 \mathrm{~mm}$ posterior to bregma and $\pm 1.7 \mathrm{~mm}$ lateral to midline, and custom designed bilateral guide cannulas (Plastics One, Roanoke, VA) were lowered $6.5 \mathrm{~mm}$ from bregma to the $\mathrm{BNST}_{\mathrm{AL}}$. Four bone screws and skull adhesive were used to secure the cannulas while patency was maintained using parafilm. The incision was sutured and antibiotic/ analgesic cream was applied to the wound. The animals recovered for 1 week post surgery before experimentation.

\section{Water Avoidance Stress (WAS)}

Repeated WAS is a validated model of psychological stress that induces anxiety, and somatic and visceral hypersensitivity (Bradesi et al, 2005; Myers and Greenwood-Van Meerveld, 2012; Tran et al, 2013). Rats were placed on a square platform $(8 \times 8 \times 8 \mathrm{~cm})$ mounted in the center of a white semitransparent plastic container $(50 \times 35 \times 33 \mathrm{~cm})$ filled with fresh, room temperature water to $1 \mathrm{~cm}$ below the surface of the platform. Control animals that received shamWAS (SHAM) were placed in containers without water. Animals were exposed to WAS or SHAM stress for $60 \mathrm{~min}$ each day and a total of 7 days. The fecal-pellet output during the procedure is summarized in Supplementary Figure 1S, showing the difference in autonomic output in response to WAS compared with the SHAM group.

\section{Anxiety-Like Behavior}

Anxiety-like behavior was assessed on the elevated plus-maze (EPM) as previously described (Myers and Greenwood-Van Meerveld, 2007, 2010; Tran and Greenwood-Van Meerveld, 2012b). Rats were acclimated to the experimental procedure room for $30 \mathrm{~min}$ and were then placed in the center of the EPM facing an open arm. Behavior was recorded using a video camera for $5 \mathrm{~min}$, and the footage was analyzed with the Any-Maze software (Stoelting, Wood Dale, IL). The percentage of time spent in the open arms was used to quantify anxiety-like behavior, with decreased open arm exploration and entries indicating higher anxiety. Total distance traveled was used as an index of locomotor activity.

\section{Acoustic Startle Reflex (ASR) and Prepulse Inhibition (PPI)}

Acoustic startle testing was conducted following a previously described protocol (Conti, 2005; Conti et al, 2002). Rats were placed in a startle chamber (Med Associates, St Albans, VT) for a 5-min acclimation period before the delivery of any stimulus. All stimuli were presented in the presence of a 70-dB background. In all experiments, the first and last six trials of the session were acoustic startle trials in which a $120-\mathrm{dB}$, white noise burst was presented for $40 \mathrm{~ms}$. The middle 50 trials consisted of five stimulus types presented in a pseudo-random order: acoustic startle stimuli in the absence of a prepulse stimulus (12 trials); prepulse stimuli, 3, 6, or $12 \mathrm{~dB}(20 \mathrm{~ms})$ above background, preceding the startle stimulus by $100 \mathrm{~ms}$ (10 trials of each prepulse intensity); no stimulus (eight trials). The intertrial intervals were varied and averaged $15 \mathrm{~s}$. The average startle amplitude during the $100 \mathrm{~ms}$ following the onset of each startle stimulus was recorded by an accelerometer connected to a computer. Percent PPI was calculated for each rat at each prepulse stimulus intensity as follows: (1(startle amplitude after prepulse-pulse pair/startle amplitude after pulse only) $) \times 100$ where prepulse is the average startle amplitude on trials in which there was a prepulse stimulus and startle is the average amplitude on the trials in which the startle stimulus was presented alone (excluding the first and last six trials of the session). The 24-startle stimulus-alone trials were used to analyze the effect of WAS and CRF receptor antagonists on ASR. Habituation was calculated as the percent change between the first six trials and the last six startle stimulus-alone trials.

\section{Somatic Mechanical Threshold}

A somatic mechanical threshold was determined using an electronic von Frey (IITC, Woodland Hills, CA) as previously described (Myers and Greenwood-Van Meerveld, 2010; Myers et al, 2005; Tran and Greenwood-Van Meerveld, 2012b; Tran et al, 2012c). Animals were acclimated to the procedure room for $30 \mathrm{~min}$ before unrestrained placement on an elevated mesh floor $(12 \mathrm{~mm} \times 12 \mathrm{~mm}$ grid $)$ in a clear plastic enclosure apparatus $(21 \times 27 \times 15 \mathrm{~cm})$ for an additional $30 \mathrm{~min}$. The apparatus probe $(10 \mu \mathrm{l}$ plastic tip, US Scientific, Orlando, FL.) was applied to the plantar surface of the hindpaw, and the force required to elicit withdrawal of the hind limb was recorded by an experimenter blind to 
the treatment protocol. The procedure was repeated three times using the same point on the same paw with 5-min intervals between each measurement, and the trials were averaged into a single $n$-value for each animal.

\section{Visceral Sensitivity}

Instrumentation for visceral sensitivity assessment was performed as previously described (Greenwood-Van Meerveld et al, 2001; Johnson et al, 2012; Myers et al, 2005; Tran et al, 2013; Tran and Greenwood-Van Meerveld, 2012b; Tran et al, 2012c). Briefly, rats were fasted for $16-18 \mathrm{~h}$ to ensure that the colon was free of fecal pellets, allowing for the insertion of the colonic balloon catheter. On the morning of the experiment, rats were transported to the testing room and anesthetized with 2-5\% isoflurane (Aerrane, Baxter Healthcare, Deerfield, IL). A colonic balloon $(5 \mathrm{~cm})$ was inserted $11 \mathrm{~cm}$ past the anus into the colon and secured to the base of the tail with tape. Rats were allowed $30 \mathrm{~min}$ to recover from anesthesia before colorectal distension (CRD). The conscious, freely moving animals' visceromotor reflex (VMR) to isobaric distension pressures (0-60 mm Hg) was used as an indicator of visceral sensitivity. The colonic balloon catheter was attached to a Distender Series IIR Barostat (G \& J Electronics, Toronto, Ontario, Canada), and the VMR was quantified by the number of abdominal contractions resulting in animal arching in response to CRD (Gibney et al, 2010; Tran et al, 2013). Each constant pressure distension series consisted of a $10-\mathrm{min}$ basal recording period at $0 \mathrm{~mm} \mathrm{Hg}$ and a $10-\mathrm{min}$ inflation period at 20,40, and $60 \mathrm{~mm} \mathrm{Hg}$ separated by 10 -min rest periods. To prevent experimental bias, the experimenter was blind to the treatment protocol.

\section{Autonomic Response to a Novel Environment Stressor}

Exposure to a novel environment stressor (NES) was used to assess the endocrine response to an acute stressor. In a new well-lit procedure room, the animals were removed from their home cages and placed in a clear empty plastic container $(62.230 \mathrm{~cm} \times 45.085 \mathrm{~cm} \times 33.655 \mathrm{~cm})$. The animals were left undisturbed for $30 \mathrm{~min}$. Immediately following the stressor, the animals were killed and blood was collected for analysis of serum CORT and adrenocorticotropic hormone (ACTH).

\section{Sample Collection}

Rats were anesthetized with isoflurane (2-5\%) followed by rapid decapitation. Blood samples were collected to evaluate CORT and ACTH levels. The time (approximately 09001100 hours) was selected to be consistent with our previous experiments investigating the $\mathrm{BNST}_{\mathrm{AL}}$ (Tran et al, 2012c), and is a period that CORT levels are known to be constant and minimal (Allen and Kendall, 1967), which improves resolution when examining stress responses. Approximately $1 \mathrm{ml}$ of trunk blood was collected and centrifuged at $2500 \mathrm{~g}$ for $10 \mathrm{~min}$. The serum was separated and stored for subsequent CORT and ACTH analyses with enzyme-linked immunosorbent assay using kits purchased from Immuno Diagnostic Systems (Fountain Hills, AZ) and Novus Biologicals (Littleton, CO), respectively. The sensitivity for each kit was $0.55 \mathrm{ng} / \mathrm{ml}$ and $1 \mathrm{pg} / \mathrm{ml}$, respectively. Brains were extracted, flash-frozen in pre-chilled 2-methylbutane, and were stored in a plastic container at $-80{ }^{\circ} \mathrm{C}$ until cryosectioning. In animals that were not treated with infusions, brains were extracted from the skull and a 1-mm coronal section was taken from $-0.24 \mathrm{~mm}$ posterior to bregma containing the $\mathrm{BNST}_{\mathrm{AL}}$. A 1-mm hole-punch was used to collect bilateral samples predominantly containing the $\mathrm{BNST}_{\mathrm{AL}}(-6.0$ from the dorsal surface of the brain and \pm 1.7 from midline). Samples were immediately flash-frozen on dry ice and stored at $-80{ }^{\circ} \mathrm{C}$ until RNA and protein extractions.

\section{RNA and Protein Extraction}

Total RNA and protein were extracted from the same tissue preparation with the SurePrep Purification Kit (Fischer BioReagents, Fair Lawn, NJ) using the protocol for RNA and protein extraction. Protein was quantified using the Experion Pro260 system (Bio-Rad, Hercules, CA) and RNA was quantified using the Experion RNA StdSens system (Bio-Rad). The samples were aliquoted and stored at $-80^{\circ} \mathrm{C}$ for subsequent qRT-PCR and western blot analysis.

\section{CRF Expression}

Extraction of RNA was followed by cDNA synthesis using $\mathrm{RT}^{2}$ First Strand cDNA Kit and qPCR using SYBR Green qPCR Mastermix in a total reaction volume of $25 \mu$ l (Qiagen, Valencia, CA). Samples were run in triplicates and 'no template' conditions served as a negative control. Samples were normalized to 28S rRNA and sequences for both primers were described previously (Tran et al, 2013). The reaction was performed on an Applied Biosystems StepOne Plus Real-Time PCR System Thermal Cycling Block (Carlsbad, CA) with the initial denaturation at $95{ }^{\circ} \mathrm{C}$ for $15 \mathrm{~min}$ and subsequent denaturation at $94^{\circ} \mathrm{C}$ for $10 \mathrm{~s}$. The samples were annealed at $64.0^{\circ} \mathrm{C}$ for $30 \mathrm{~s}$ and were extended at $72{ }^{\circ} \mathrm{C}$ for $30 \mathrm{~s}$ for a total of 40 cycles, with a final extension at $72{ }^{\circ} \mathrm{C}$ for $10 \mathrm{~min}$. Melting curves were performed at the end of each experiment from 72 to $95^{\circ} \mathrm{C}$ in 90 -s intervals that showed only a single peak near $78.9^{\circ} \mathrm{C}$ for $28 \mathrm{~S}$ and $90.09{ }^{\circ} \mathrm{C}$ for $\mathrm{CRF}$. The relative quantity of CRF mRNA from each sample was calculated as the difference in $C_{t}$ for target minus $C_{\mathrm{t}}$ for $28 \mathrm{~S}$ rRNA $\left(\Delta C_{\mathrm{t}}\right)$ and calibrated to $C_{\mathrm{t}}$ of SHAMtreated control sample $\left(\Delta \Delta C_{\mathrm{t}}\right)$. Fold-change in transcription is expressed as $2^{(-\Delta \Delta C \mathrm{t})}$.

\section{CRF Receptor Expression}

Approximately $30 \mu \mathrm{g}$ of total protein extract was solubilized in Laemmli buffer supplemented with 2-mercaptoethanol and denatured at $95^{\circ} \mathrm{C}$ for $5 \mathrm{~min}$. The samples were then resolved on a $4-20 \%$ gradient Tris-Glycine polyacrylamide gel (Bio-Rad) using sodium dodecyl sulfate polyacrylamide gel electrophoresis and transferred to a nitrocellulose membrane (Millipore, Billerica, MA). The membranes were blocked with $1 \%$ casein in TBS for $1 \mathrm{~h}$. Blots were then incubated for $2 \mathrm{~h}$ with primary antibodies anti-CRF $\mathrm{F}_{1}$ receptor (Abcam, Cambridge, MA), anti-CRF 2 receptor (Abcam), or anti-GAPDH (Sigma-Aldrich, St Louis, MO) was used for normalization. Following antibody incubation, the blots 
were washed in three changes of TBS-T and incubated for $1 \mathrm{~h}$ with horseradish peroxidase (HRP)-conjugated secondary anti-rabbit or anti-mouse antibodies (Millipore). After three more washes in TBS-T, bands were visualized with ECL Western Blot Detection Kit (Amersham, Piscataway, $\mathrm{NJ}$ ) and imaged using an Omega $12 \mathrm{iC}$ chemiluminescent imager (UltraLum, Claremont, CA). Densitometry was performed using the ImageJ software (NIH, Bethesda, MD).

\section{Histology and Retrograde Labeling}

Following the last experimental day, animals were infused with $0.5 \mu \mathrm{l}$ of HRP to determine diffusion radius. The localization and identification of the area of diffusion of the micropellets were verified from post-mortem histological samples. Serial coronal sections $(30 \mu \mathrm{m})$ were cryosectioned at $-20^{\circ} \mathrm{C}$ and mounted onto pre-subbed slides. Positive HRP labeling was revealed using the Betazoid DAB Chromogen Kit (Biocare Medical, LLC, Concord, CA). Sections were then counterstained with Hematoxylin and Tacha's Bluing Solution (Biocare Medical) to determine neuronal damage. Visualization of cell bodies and verification of micropellet placement were performed using light microscopy.

As shown in Figure 1a, implantation of cannulas and infusions did not damage the $\mathrm{BNST}_{\mathrm{AL}}$. Chromogenic staining for HRP revealed significant staining of the $\mathrm{BNST}_{\mathrm{AL}}$ and minor outlying regions. Although the use of HRP gives a qualitative estimate of the migration pattern of the infusions, it is unknown how precisely the diffusion properties of HRP match the different drugs used in this study. Importantly, spread into the ventricular system adjacent to the dorsal aspect of the $\mathrm{BNST}_{\mathrm{AL}}$ is a possibility, but is unlikely to be effective, given the low volume and concentration. To an extent, HRP can also be used as a retrograde label to determine the origin of projections to the $\mathrm{BNST}_{\mathrm{AL}}$ (Figure 1b). For additional verification of infusion accuracy, sections were collected from the brain regions that project to the BNST (Dong and Swanson, 2004), including the paraventricular nucleus of the hypothalamus $(\mathrm{PVN})$, the $\mathrm{CeA}$, medial nucleus of the thalamus (MDN), the periaqueductal grey (PAG), and nucleus accumbens (NTS). Following cryosectioning and processing with $\mathrm{DAB}$, strong positive staining was revealed in the CeA, $\mathrm{mPVN}$, and NTS. Less intense staining was seen in the PAG and MDN.

\section{Experimental Design}

Series 1: two groups of rats were employed in which animals were exposed to WAS or sham-WAS (SHAM; $n=6$ /group). Following the procedure, animals were killed and tissue samples were collected from the BNST $\mathrm{AL}_{\mathrm{AL}}$ to quantify CRF mRNA and CRF receptor protein expression. Series 2: SHAM control animals were implanted with cannulas ( $n=6$ /group) localized to the $\mathrm{BNST}_{\mathrm{AL}}$ to investigate the effect of a selective $\mathrm{CRF}_{1}$ receptor antagonist (CP376395; $10 \mathrm{mg} / \mathrm{ml}$ ), a selective $\mathrm{CRF}_{2}$ receptor antagonist (Astres$\sin _{2} \mathrm{~B} ; 100 \mu \mathrm{M}$ ), or vehicle (VEH; normal saline) infused a rate of $0.1 \mu \mathrm{l} / \mathrm{min}\left(0.5 \mu \mathrm{l}\right.$ total) directly into each $\mathrm{BNST}_{\mathrm{AL}}$ $\sim 30 \mathrm{~min}$ before each behavior test. A summary of the cannula localization is illustrated in Figure 1c. One animal (VEH) was excluded because of placement issues. Series 3: the effect of CRF antagonism or VEH on WAS-induced anxiety-like behavior, mechanical allodynia, and visceral sensitivity ( $n=6$ /group) was assessed. Animals were exposed to the 7-day WAS protocol, and $24 \mathrm{~h}$ following the last stressor, animals were infused with CP376395, Astressin ${ }_{2} \mathrm{~B}$, or VEH and their behaviors were assessed as previously described. Series 4: the effect of CRF antagonism on the ASR and PPI ( $n=5$ /group) was investigated following the WAS protocol. After the last experimental day, animals from experimental series 2-4 were killed and the post-mortem brains were used for histology and verification of cannula placement.

\section{Drugs and Chemicals}

Both CP376395 and Astressin ${ }_{2}$ B were purchased from Tocris Biosciences (Minneapolis, $\mathrm{MN}$ ) and dissolved in normal saline $(0.9 \% \mathrm{NaCl})$. The dose of $\mathrm{CP} 376395$, a selective $\mathrm{CRF}_{1}$ receptor antagonist was chosen to be consistent with our previous studies (Johnson et al, 2012; Tran et al, 2012c), and the dose of Astressin ${ }_{2} \mathrm{~B}$, a selective $\mathrm{CRF}_{2}$ receptor antagonist, was based on a study by (Ohmura et al, 2010). Although biphasic effects are possible with $\mathrm{CRF}_{2}$ receptor antagonist, the dose of Astressin ${ }_{2} B$ was carefully selected to avoid such effects. Astressin ${ }_{2} B$ has a comparable potency to block $\mathrm{CRF}_{2}$ receptors as the predecessor antisauvagine-30, but with 10 -fold less affinity for $\mathrm{CRF}_{1}$ receptors (Zorrilla et al, 2013). In addition to this advantage, the concentration of Astressin ${ }_{2} B$ used in the present study was approximately fourfold less than the concentration reported to perturb $\mathrm{CRF}_{1}$ receptor-mediated acoustic startle responses using antisauvagine-30 (Risbrough et al, 2004), and approximately sixfold less for gastrointestinal responses (Chen et al, 2005).

\section{Data Analysis}

Gene expression, anxiety-like behavior, and somatic mechanical sensitivity in response to SHAM or WAS were analyzed using a Student's unpaired $t$-test, and a one-way analysis of variance (ANOVA) was used when comparing antagonist treatments within the SHAM or WAS groups followed by Bonferroni's post hoc test. A two-way ANOVA was used to compare main effects of stress protocol and antagonist treatment followed by Tukey's test for multiple comparisons. Owing to repeated measures in the ASR, PPI, and visceral sensitivity assays, these results were analyzed with a two-way ANOVA with repeated measures (ANOVARM) with Bonferroni's post hoc test. In all tests, significance was determined as $P<0.05$ using the GraphPad Prism Software ver. 6.0b (La Jolla, CA).

\section{RESULTS}

Repeated WAS Sensitizes the CRF and CRF Receptors in the $\mathrm{BNST}_{\mathrm{AL}}$

As illustrated in Figure 2a, animals exposed to the WAS protocol had a significant $2.06 \pm 0.42$-fold increase $\left(t_{(10)}=2.442 ; P=0.02\right)$ in CRF mRNA in tissue samples collected from the $B N S T_{A L}$ compared with SHAM controls. On the basis of optical density of western blot bands 
a

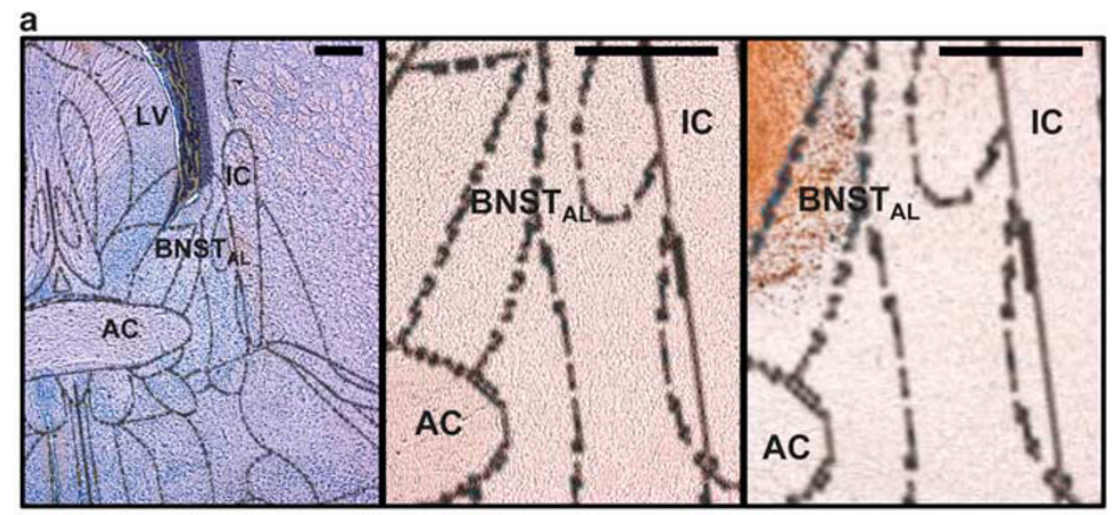

b

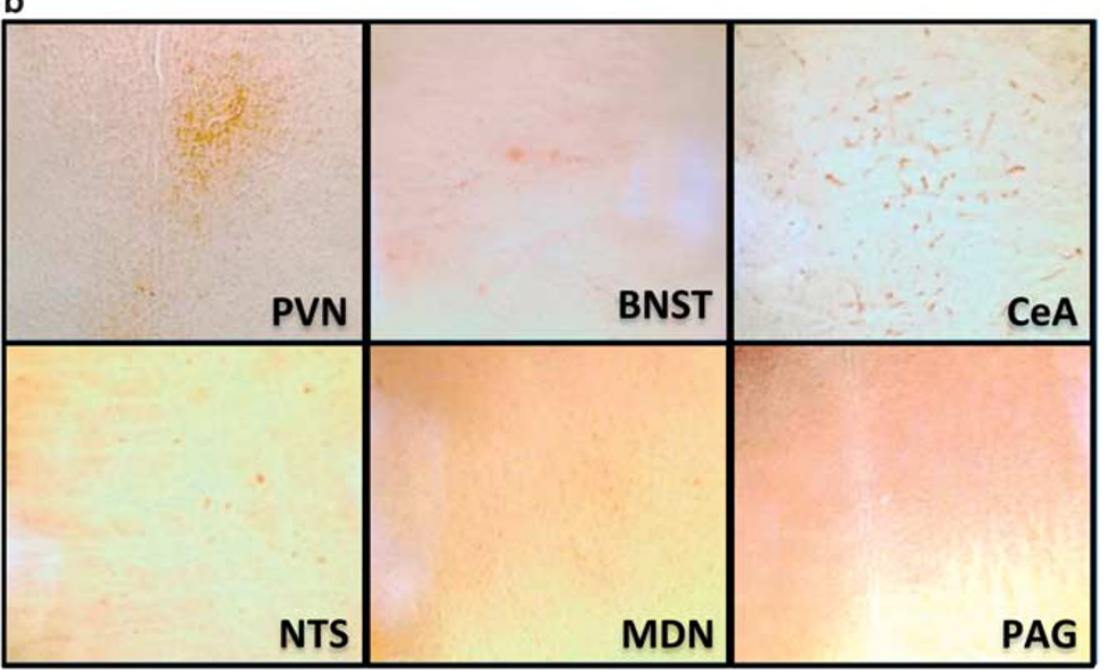

c

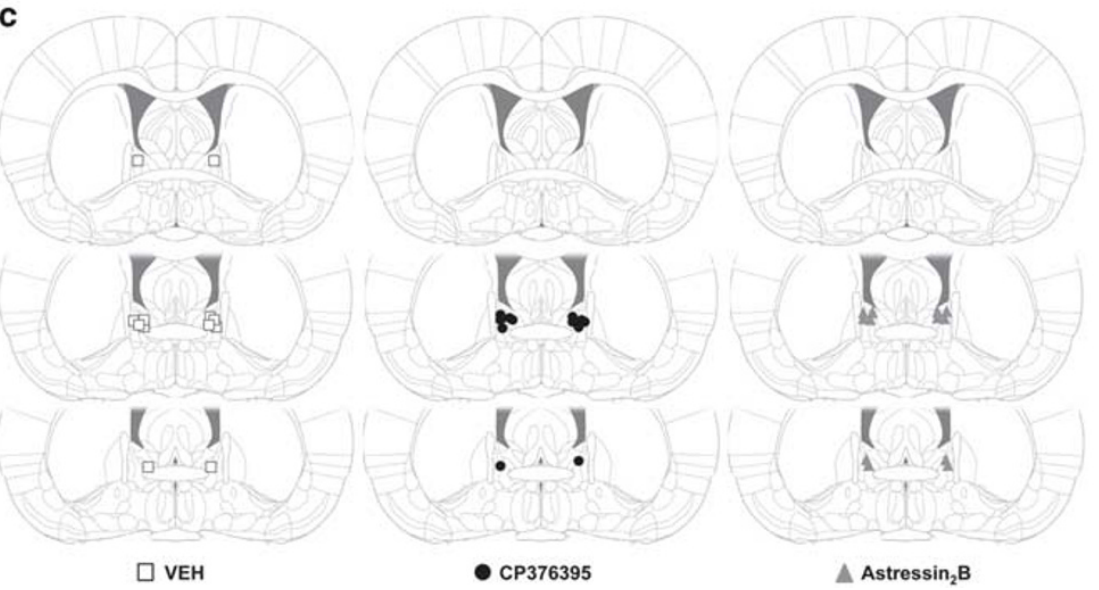

Figure I Infusions are restricted to the anteriolateral bed nucleus of the stria terminalis (BNST $\mathrm{AL}$ ). Before being killed, animals were infused with horseradish peroxidase (HRP) to assess diffusion radius. (a) Post-mortem tissue slices were stained with cresyl violet to determine viability (left) and show minimal damage to the BNST. Negative control (middle), and the addition of DAB substrate (right), show that infusions were restricted to the BNST AL $_{\text {and }}$ minor outlying areas. (b) The BNST receives inputs from regions associated with sensory and affect processing. To verify infusion accuracy, sections were collected from the regions that project to the BNST including the paraventricular nucleus (PVN), the central amygdala (CeA), medial nucleus (MDN), the periaqueductal grey (PAG), and nucleus accumbens (NTS). Positive staining was revealed in the CeA, PVN, and NTS. Minimal staining was seen in the MDN, and not visible in the PAG. (c) Brain atlas sections for coordinates (from top) bregma $-0.12,-0.24,-0.36$, respectively, depicting the localization of each cannula placement.

(Figure $2 \mathrm{~b}$ and $\mathrm{c}$ ), animals exposed to WAS had higher $\mathrm{CRF}_{1}$ receptor expression (WAS: $4.19 \pm 0.63$; SHAM: $1.87 \pm 0.16$; $\left.t_{(10)}=3.555 ; P<0.01\right)$ and $\mathrm{CRF}_{2}$ receptor expression levels
$\left(\mathrm{CRF}_{2}\right.$ : WAS: $3.70 \pm 0.33$; SHAM: $1.65 \pm 0.19 ; t_{(10)}=5.406$; $P<0.001)$. The ratio between $\mathrm{CRF}_{1}$ and $\mathrm{CRF}_{2}$ receptors (Figure $2 \mathrm{~d}$ ) was also increased $\left(t_{(10)}=2.282 ; P=0.03\right)$ in 
a

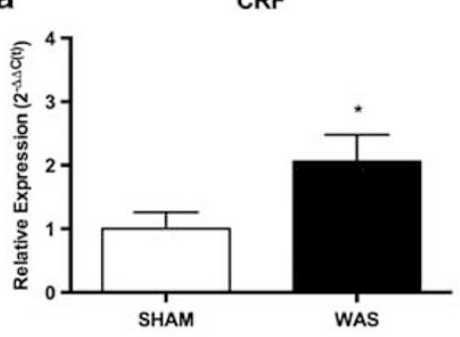

b

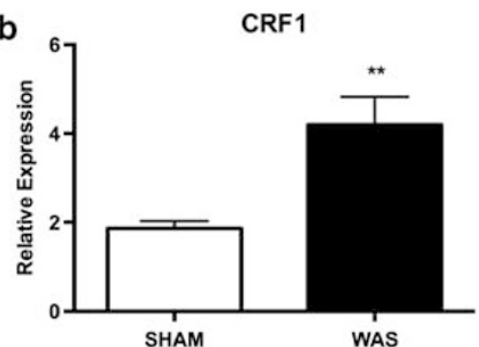

C

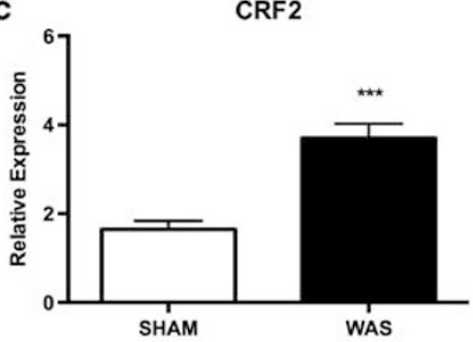

d

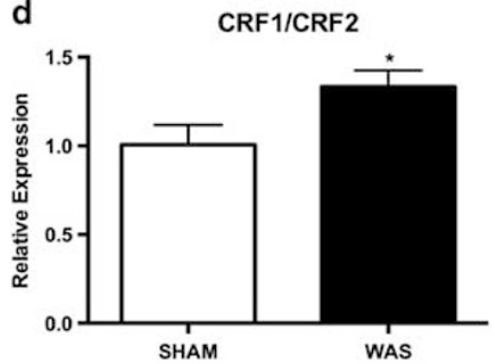

SHAM
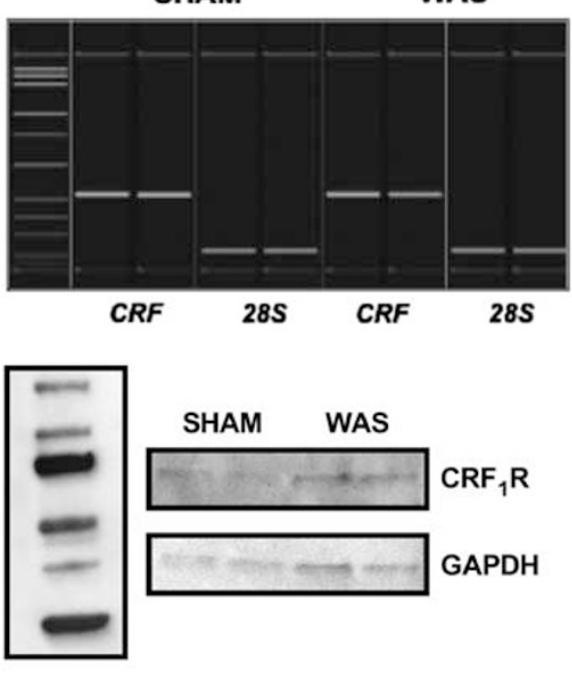

SHAM

WAS

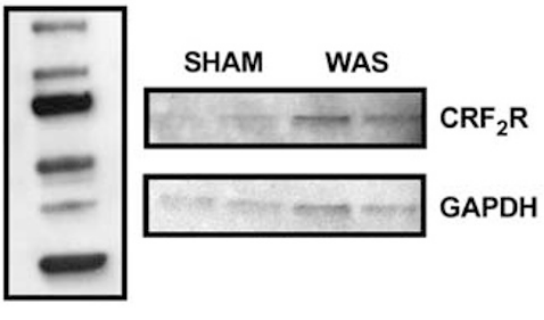

e

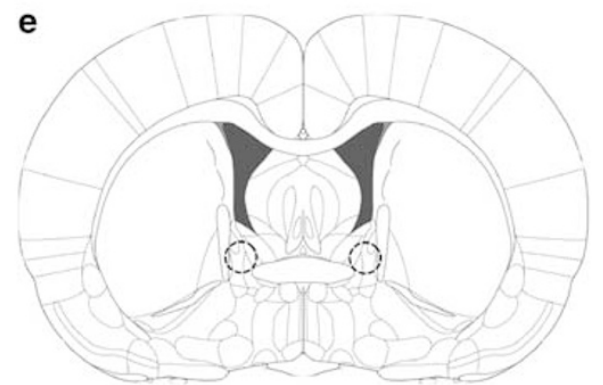

Figure 2 Repeated water avoidance stress (WAS) increases corticotropin-releasing factor (CRF) and CRF receptor expression. CRF expression was assessed using $\mathrm{ART}$-PCR, whereas $\mathrm{CRF}_{1}$ and $\mathrm{CRF}_{2}$ receptors were quantified using western blot analysis. Compared with animals that received SHAM stress, animals that were exposed to chronic WAS expressed higher levels of (a) CRF, (b) CRF, receptors, and (c) CRF 2 receptors in the anteriolateral bed nucleus of the stria terminalis (BNST $\mathrm{AL}$ ). (d) The ratio between CRFI and CRF2 was higher following WAS compared with SHAM-treated animals. (e) The target location of the micropunches is illustrated. Data represent mean $\pm \mathrm{SEM}$; $* P<0.05$, $* * P<0.0$ I, and $* * * *<0.00$ I by Student's unpaired $t$-test; $n=6 /$ group.

animals exposed to WAS $(1.33 \pm 0.09)$ compared with SHAM treatment $(1.01 \pm 0.11)$. A schematic diagram of the target location of the micropunches is illustrated in Figure 2e.

\section{Effects of WAS on Anxiety, Pain, and HPA Output}

Anxiety-like behavior was assessed on the EPM, and percent time spent exploring the open arms is shown (Supplementary Figure 1SA). Animals exposed to WAS spent significantly less time $\left(t_{(10)}=3.384 ; P<0.01 ; 49.8 \pm 3.18 \%\right)$ exploring the open arms than SHAM controls (76.4 \pm $7.19 \%)$, indicating increased anxiety-like behavior. No changes in locomotor activity were observed (Supplementary Figure 1SB), and there was no significant difference in total distance traveled $\left(t_{(10)}=0.5283 ; P=0.61\right.$; SHAM: $11.9 \pm$ $1.13 \mathrm{~m}$, WAS: $12.9 \pm 1.53 \mathrm{~m})$.

Following anxiety assessment, pain behaviors were examined by quantifying somatic mechanical threshold (Supplementary Figure 1SC) and the VMR to graded pressures of CRD (Supplementary Figure 1SD). Somatic mechanical sensitivity was assessed by quantifying the mechanical force required to illicit a reflexive withdrawal of the hindpaw. Animals exposed to WAS showed a significant decrease in somatic mechanical threshold $\left(t_{(10)}=11.82\right.$; $P<0.001 ; 52.8 \pm 1.68 \mathrm{~g}$ ) compared with SHAM controls 
(76.7 $\pm 1.12 \mathrm{~g})$, suggesting an increase in somatic sensitivity. Moreover, the animals exposed to the WAS protocol exhibited an increased sensitivity to visceral stimuli. Specifically, in response to CRD there was a significant effect of distension pressure $\left(\mathrm{F}_{(3,30)}=506.9 ; P<0.001\right)$, a significant effect of stress protocol $\left(\mathrm{F}_{(1,10)}=5.510\right.$; $P=0.04)$, and a significant interaction $\left(\mathrm{F}_{(3,30)}=3.421\right.$; $P=0.03$ ).

One day following the last behavioral assessment, the animals were exposed to NES before being killed to assess HPA output. As shown in Supplementary Figure 1SE and F, compared with SHAM, animals that were previously exposed to WAS had elevated serum CORT $\left(t_{(10)}=3.504\right.$; $P<0.01$; SHAM: $595.25 \pm 86.538 \mathrm{ng} / \mathrm{ml}$, WAS: $1184.7 \pm$ $144.26 \mathrm{ng} / \mathrm{ml})$ and serum ACTH $\left(t_{(10)}=4.617 ; P=0.001\right.$; SHAM: $421.89 \pm 52.920 \mathrm{pg} / \mathrm{ml}$, WAS: $866.89 \pm 80.550 \mathrm{pg} / \mathrm{ml}$ ) in response to the NES.

\section{Effect of $\mathrm{CRF}_{1}$ and $\mathrm{CRF}_{2}$ Receptor Antagonism in the BNST $_{\mathrm{AL}}$ on Basal Behaviors}

Control SHAM animals were treated with VEH, a selective $\mathrm{CRF}_{1}$ antagonist, or a selective $\mathrm{CRF}_{2}$ antagonist. As illustrated in Figure 3a, there was a significant effect of infusion on total time spent exploring the open $\operatorname{arm}\left(\mathrm{F}_{(2,14)}=9.780\right.$; $P<0.01) . \mathrm{CRF}_{2}$ receptor antagonism with Astressin ${ }_{2} \mathrm{~B}$ decreased open arm time by $31.7 \pm 8.57 \%(P<0.01)$. However, $\mathrm{CRF}_{1}$ receptor antagonist treatment with $\mathrm{CP} 376395$ produced no effect on anxiety-like behavior $(P>0.05)$. There was no significant effect of infusion on total distance traveled (Figure $4 \mathrm{~b} ; \mathrm{F}_{(2,14)}=0.3858 ; P=0.69$ ). As shown in Figure $3 c$, we found a significant effect of infusion on the somatic mechanical threshold $\left(\mathrm{F}_{(2,14)}=102.1 ; P<0.001\right)$. $\mathrm{CRF}_{2}$ antagonist treatment with Astressin ${ }_{2} \mathrm{~B}$ decreased the threshold by $19.7 \pm 1.74 \mathrm{~g}(P<0.001)$. There was also a significant effect of antagonist infusion on the VMR to CRD (Figure 3d; $\mathrm{F}_{(2,14)}=58.35 ; P<0.001$ ), in addition to a significant effect of distension pressure $\left(\mathrm{F}_{(3,14)}=415.6\right.$; $P<0.001)$ and interaction $\left.\left(\mathrm{F}_{(2,}, 14\right)=13.58 ; \quad P<0.001\right)$. Significant decreases in the number of abdominal contractions were seen at 20,40, and $60 \mathrm{~mm} \mathrm{Hg}$ for treatment with CP376395 $(P<0.001)$ or Astressin 2 B $(P<0.001)$.

\section{The Effect of $\mathrm{CRF}_{1}$ and $\mathrm{CRF}_{2}$ Antagonism in the $\mathrm{BNST}_{\mathrm{AL}}$} on WAS-Induced Behaviors

Animals were exposed to the WAS protocol, and behaviors were evaluated $24 \mathrm{~h}$ following the final stressor. Before behavioral assessments, the animals were treated with a selective $\mathrm{CRF}_{1}$ antagonist, a selective $\mathrm{CRF}_{2}$ antagonist, or control VEH and the results are illustrated in Figure 4a. Overall there was a significant effect of treatment on total time spent exploring the open arms $\left(P<0.001 ; \mathrm{F}_{(2,14)}=\right.$ 12.78 ), and post hoc analysis revealed a $29.4 \pm 6.13 \%$ increase in open arm time $(P<0.001)$ with $\mathrm{CP} 376395$ infusions and no significant difference of Astressin ${ }_{2} B$ $(P=0.69)$ compared with VEH control. There was no significant effect of treatment on total distance traveled (Figure $4 \mathrm{~b} ; P=0.63 ; \mathrm{F}_{(2,14)}=0.4719$ ). Following WAS, there was a significant main effect of antagonist infusion (Figure 4c; $\left.P<0.001 ; \quad \mathrm{F}_{(2,14)}=32.86\right)$. Treatment with CP376395 increased the threshold $22.1 \pm 3.64 \mathrm{~g}(P<0.001)$ compared with VEH; however, infusions of Astressin ${ }_{2} B$ had no effect $(P=0.53)$. In the visceral sensitivity assay, there
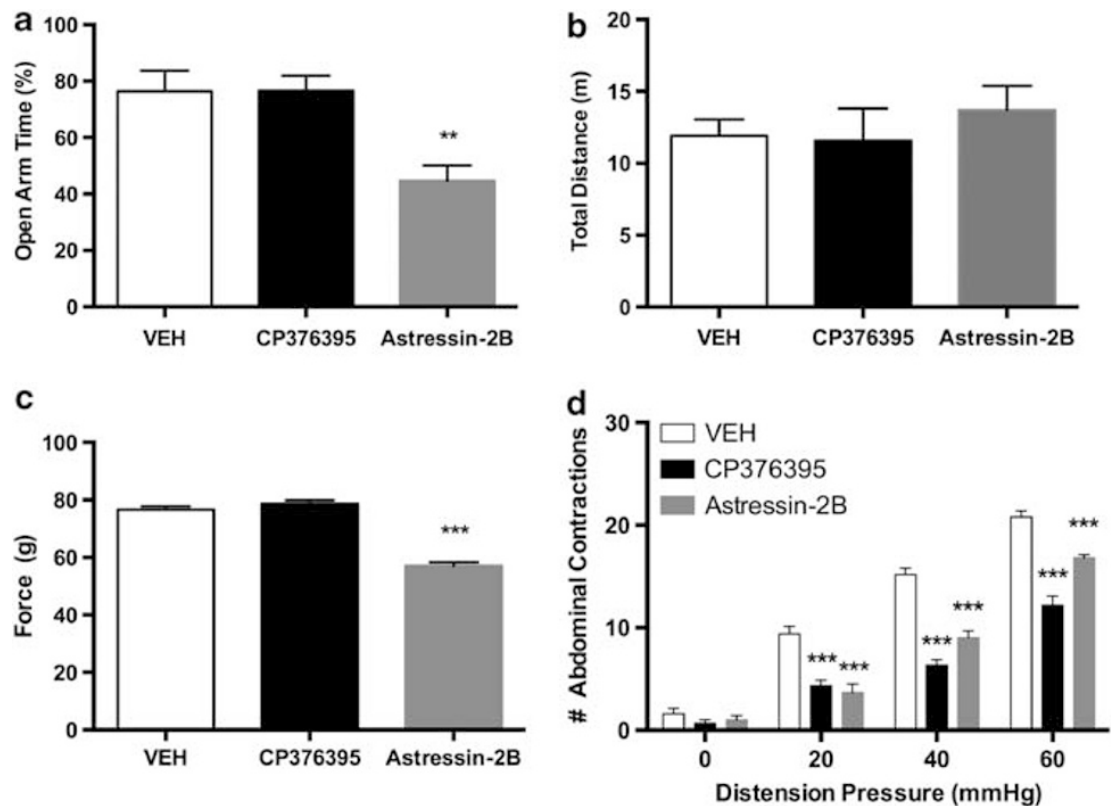

Figure 3 Effect of corticotropin-releasing factor (CRF) receptor antagonists on baseline behavior. Animals implanted with bilateral cannulas localized to the anteriolateral bed nucleus of the stria terminalis (BNST $\mathrm{AL}$ ) received infusions of either vehicle $(\mathrm{VEH}$; normal saline; $n=5)$, the $C R F_{1}$ receptor antagonist CP376395 (I $0 \mathrm{mg} / \mathrm{ml} ; n=6)$, or the $\mathrm{CRF}_{2}$ receptor antagonist Astressin $2 \mathrm{~B}(100 \mu \mathrm{M} ; n=6)$. Compared with VEH infusions, treatment with CP376395 had no effect on (a) the percent time spent exploring the open arms, (b) total distance traveled, or (c) somatic mechanical threshold. In contrast, infusion with Astressin ${ }_{2} B$ decreased open arm exploration without changing total distance traveled, and decreased the somatic mechanical threshold. (d) Both antagonists decreased the visceromotor reflex (VMR) relative to $\mathrm{VEH}$ treatment. Data represent mean $\pm \mathrm{SEM}$; $* * *<0.0 \mathrm{I}$ and $* * * * P<0.00 \mathrm{I}$ by one-way analysis of variance (ANOVA) or two-way ANOVA with repeated measures (ANOVA-RM) with Bonferonni post hoc analysis. 

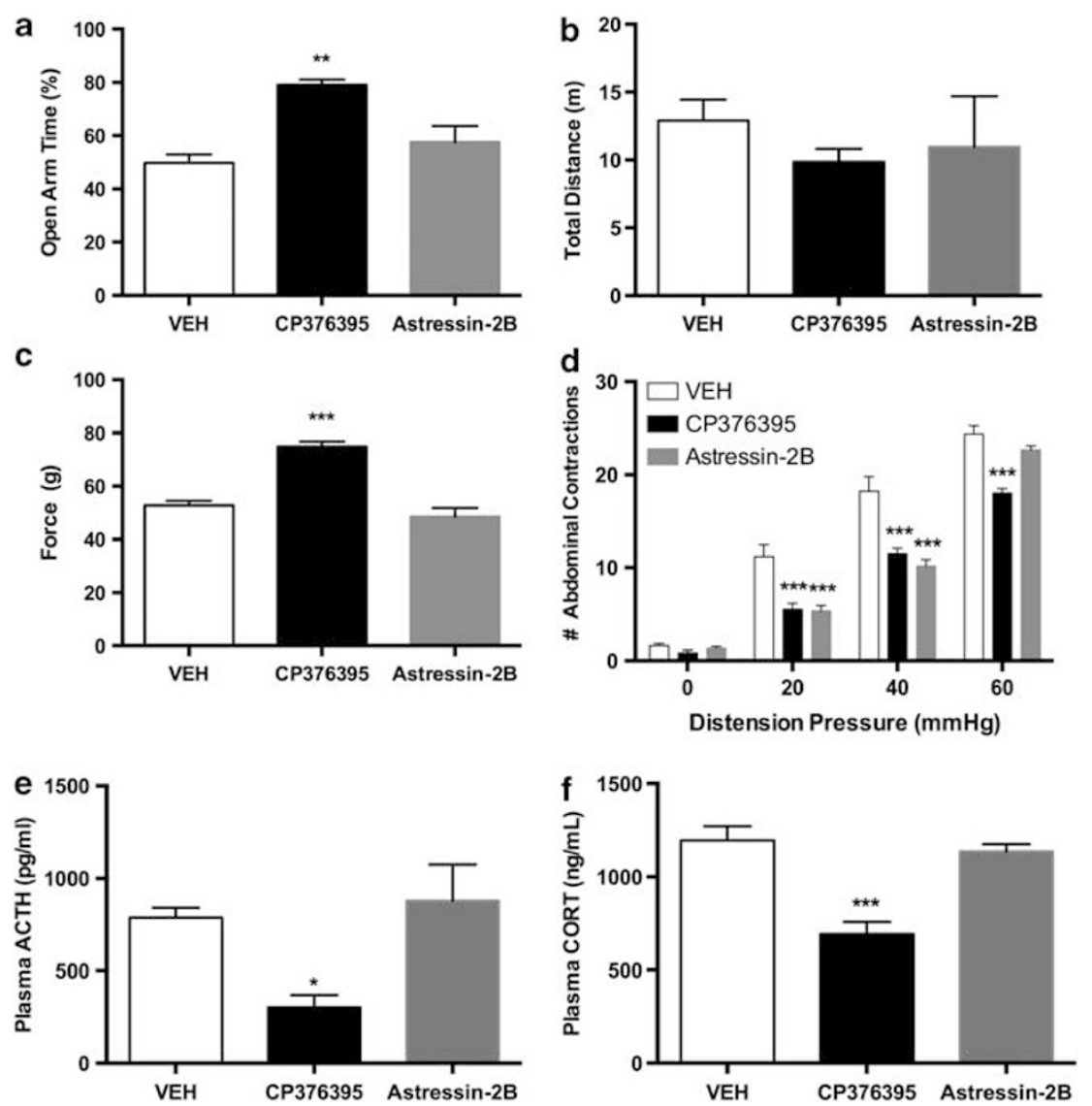

Figure 4 Effect of corticotropin-releasing factor (CRF) receptor antagonist following water avoidance stress (WAS). Animals were implanted with bilateral cannulas localized to the anteriolateral bed nucleus of the stria terminalis (BNST $T_{\mathrm{AL}}$ ) and exposed to the WAS protocol. Before behavioral assessment, the animals received infusions of either vehicle (VEH; normal saline; $n=5)$, the CRF, receptor antagonist CP376395 (I0 mg/ml; $n=6)$, or the $\mathrm{CRF}_{2}$ receptor antagonist Astressin $\mathrm{B}(100 \mu \mathrm{M} ; n=6)$. Compared with WAS-treated animals with $\mathrm{VEH}$ infusions, (a) antagonizing $\mathrm{CRF}_{1}$ receptors increased percent time spent on the open arm. Blocking $\mathrm{CRF}_{2}$ had no effect on the time spent exploring the open arm. (b) Neither $\mathrm{CRF}_{1}$ nor $\mathrm{CRF}_{2}$ receptor

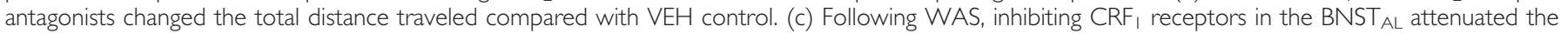
decrease in somatic mechanical threshold induced by WAS compared with VEH infusions, but blocking $\mathrm{CRF}_{2}$ receptors had no effect on threshold. (d) Both $\mathrm{CRF}_{1}$ and $\mathrm{CRF}_{2}$ decreased the number of abdominal contractions in response to colorectal distension. At the highest distension pressure, $\mathrm{CRF}_{2}$ receptor was no longer significantly different from VEH. (e) Serum ACTH and (f) corticosteroid (CORT) output was quantified following 30 min of novel environment stress. Animals exposed to WAS and infused with CP376395 had decreased plasma ACTH and CORT compared with animals exposed to the WAS protocol and infused with VEH or Astressin ${ }_{2} B$. Data represent mean $\pm S E M$; $* P<0.05$, $* * P<0.0$ I, and $* * * P<0.00$ I by one-way analysis of variance (ANOVA) or two-way ANOVA with repeated measures (ANOVA-RM) with Bonferonni post hoc analysis.

was a significant main effect of infusion (Figure $4 \mathrm{~d}$; $\left.P<0.001 ; \mathrm{F}_{(2,14)}=21.67\right)$, a significant effect of distension pressure $\left(P<0.001 ; \mathrm{F}_{(3,14)}=710.0\right)$, and a significant interaction $\left(P<0.001 ; \mathrm{F}_{(2,14)}=14.12\right)$. Significant differences were seen at 20 and $40 \mathrm{~mm} \mathrm{Hg}$ for both $\mathrm{CP} 376395$ and Astressin ${ }_{2} B$ infusions, respectively, compared with VEH $(P<0.001)$, but at $60 \mathrm{~mm} \mathrm{Hg}$ only CP376395 had a significant effect $(P<0.001)$. Following exposure to NES, HPA responses were assessed (Figure $4 \mathrm{e}$ and $\mathrm{f}$ ). There was a significant effect of infusion on plasma ACTH $\left(P=0.01 ; \mathrm{F}_{(2,14)}=6.312\right)$ and CORT $(P<0.001$; $\left.\mathrm{F}_{(2,14)}=19.61\right)$. Animals infused with $\mathrm{CRF}_{1}$ receptor antagonist had an average CORT concentration that was lesser $(P<0.001 ; \quad 691.62 \pm 66.507 \mathrm{ng} / \mathrm{ml})$ than animals treated with VEH $(1196.1 \pm 74.641 \mathrm{ng} / \mathrm{ml})$ or $\mathrm{CRF}_{2}$ receptor antagonist $(1135.3 \pm 40.138 \mathrm{ng} / \mathrm{ml})$. Animals infused with a $\mathrm{CRF}_{1}$ receptor antagonist had significantly lesser $(P=0.04$; $302.13 \pm 65.989 \mathrm{pg} / \mathrm{ml}$ ) serum ACTH than animals treated with $\mathrm{CRF}_{2}$ receptor antagonist $(878.40 \pm 196.33 \mathrm{pg} / \mathrm{ml})$ or VEH $(798.75 \pm 66.845 \mathrm{pg} / \mathrm{ml})$.

\section{The Effect of WAS on CRF Antagonism in the $\mathrm{BNST}_{\mathrm{AL}}$}

To determine whether the WAS procedure affects the outcomes following infusion with the CRF antagonists, the data were pooled between experimental series and analyzed. On the EPM, there was a significant effect of infusion $\left.\left(P<0.001 ; \quad \mathrm{F}_{(2,}, 28\right)=14.82\right)$, stress protocol $\quad(P=0.04$; $\left.\mathrm{F}_{(1,28)}=4.396\right)$, and significant interaction $(P=0.01$; $\left.\mathrm{F}_{(2,28)}=5.101\right)$ on the percent time spent exploring the open arms (Figure 5a). Similarly, there was a significant effect of infusion $\left(P<0.001 ; \mathrm{F}_{(2,28)}=78.26\right)$, stress protocol $\left(P<0.001 ; \quad \mathrm{F}_{(1,28)}=55.40\right)$, and significant interaction $\left.\left(P<0.001 ; \mathrm{F}_{(2,} 28\right)=13.29\right)$ on the somatic mechanical threshold (Figure $5 \mathrm{~b}$ ). When analyzing the VMR at $60 \mathrm{~mm}$ $\mathrm{Hg}$, there was a significant effect of infusion $(P<0.001$; 

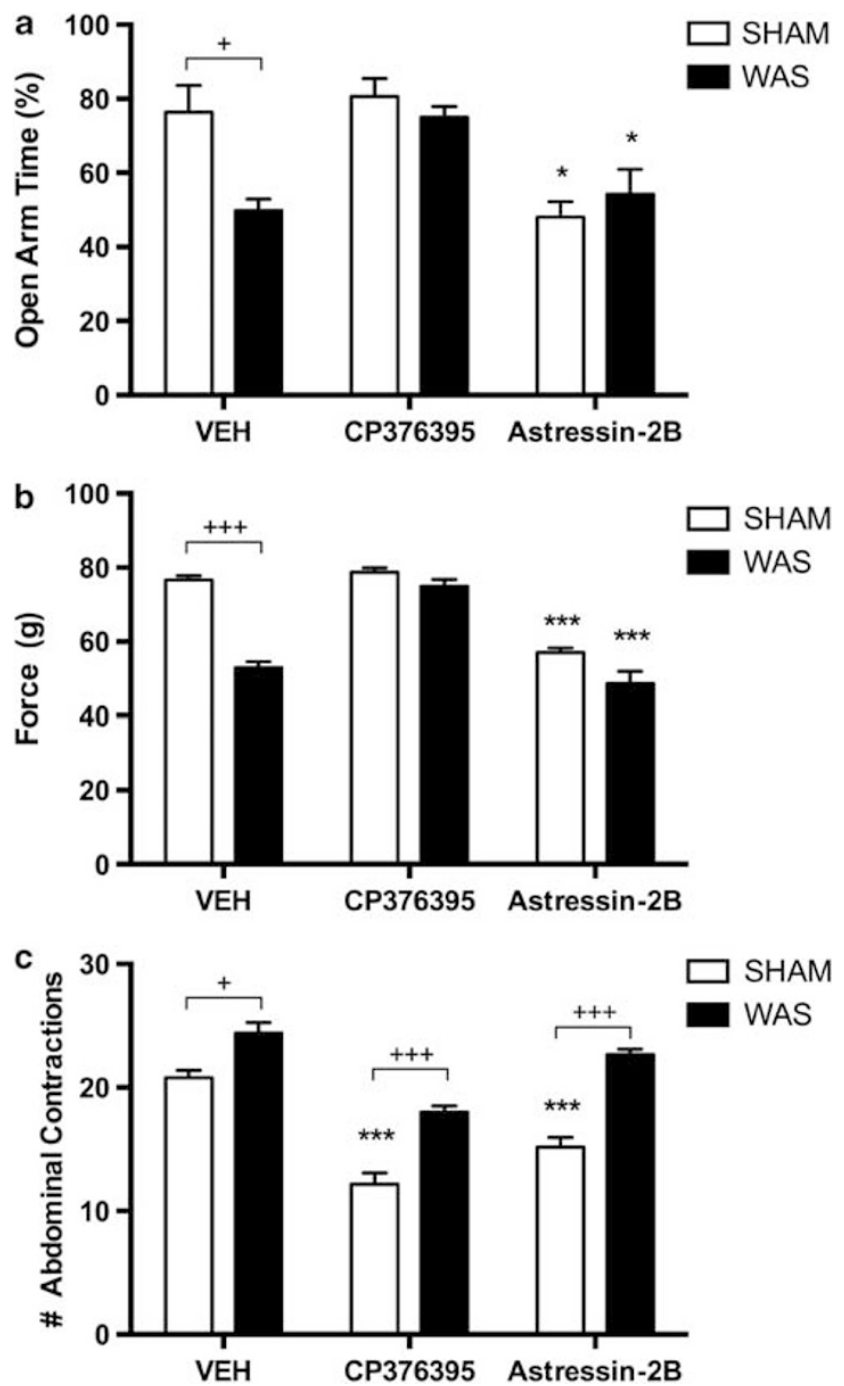

Figure 5 Effect of water avoidance stress (WAS) on corticotropinreleasing factor (CRF) receptor antagonism. The data for animals exposed to the SHAM protocol and animals exposed to the WAS protocol were compared. Overall, there were significant effects of infusion, stress protocol, and significant interaction between the two for anxiety-like behavior on the (a) percent of time spent exploring the open arm of the EPM, (b) somatic mechanical threshold, and (c) the visceromotor reflex (VMR) to colorectal distension (CRD) analyzed at $60 \mathrm{~mm} \mathrm{Hg}$ (see text for details). Data represent mean $\pm S E M$, $* P<0.05$, and $* * * P<0.001$ compared with $\mathrm{SHAM}+$ vehicle $(\mathrm{VEH})$ infusion, and ${ }^{+} p<0.05$ and ${ }^{+}+++P<0.00$ I compared with WAS + indicated infusion by two-way analysis of variance (ANOVA) with Tukey's post hoc analysis.

$\left.\mathrm{F}_{(2,28)}=54.85\right)$, stress protocol $\left(P<0.001 ; \mathrm{F}_{(1,28)}=95.28\right)$, and significant interaction $\left(P=0.03 ; \mathrm{F}_{(2,28)}=3.679\right)$ on the number of abdominal contractions in response to CRD (Figure 5c).

The Effect of $\mathrm{CRF}_{1}$ and $\mathrm{CRF}_{2}$ Antagonism into the $\mathrm{BNST}_{\mathrm{AL}}$ on WAS-Induced ASR and PPI

The effects of WAS on ASR and PPI are shown in Supplementary Figure 2S. There was a significant effect of startle intensity $\left(P<0.001 ; \mathrm{F}_{(3,30)}=134.1\right)$, a significant effect of WAS $\left(P<0.001 ; \mathrm{F}_{(1,10)}=36.73\right)$, and significant interaction $\left(P<0.001 ; \mathrm{F}_{(3,30)}=10.75\right)$ on ASR (Supplementary Figure 2SA). There was also a significant effect of WAS $\left(P<0.001 ; \mathrm{F}_{(1,10)}=370.1\right)$, a significant effect of prepulse intensity $\left(P<0.001, \mathrm{~F}_{(2,20)}=12.18\right)$, and interaction $\left(P=0.06 ; \mathrm{F}_{(2,20)}=3.198\right)$ on PPI (Supplementary Figure 2SB). A separate group of animals exposed to the WAS protocol and treated with a selective $\mathrm{CRF}_{1}$ antagonist, a selective $\mathrm{CRF}_{2}$ antagonist, or VEH showed significant differences in the acoustic startle amplitudes (Figure 5a). There was a significant effect of startle intensity $(P<0.001$; $\left.\mathrm{F}_{(3,36)}=77.97\right)$, a significant effect of infusion $(P<0.001$; $\left.\left.\mathrm{F}_{(2,} \quad 12\right)=13.31\right)$, and significant interaction $(P<0.001$; $\left.\mathrm{F}_{(6,36)}=9.207\right)$. Treatment with either $\mathrm{CP} 376395$ or Astressin 2 B significantly decreased $(P<0.001)$ the startle amplitude $419 \pm 47.2$ and $232 \pm 47.2 \mathrm{mV}$, respectively, compared with VEH control. In addition, in the PPI paradigm (Figure 5b), there was a significant effect of infusion $\left(P<0.001 ; \quad \mathrm{F}_{(2,12)}=16.26\right)$, with $\mathrm{CP} 376395$ infusions decreasing the \%PPI $\sim 18.5 \%, 22.9 \%$, and $30.77 \%$, respectively, but no significant effect of prepulse intensity $(P=0.65$, $\left.\mathrm{F}_{(2,24)}=0.4346\right)$, or interaction $\left(P=0.18 ; \mathrm{F}_{(4,24)}=1.726\right)$, and there was no significant difference in percent habituation (Figure $6 \mathrm{c} ; P=0.59 ; \mathrm{F}_{(2,12)}=0.5479$ ).

\section{DISCUSSION}

The BNST acts as a conduit between the amygdala and the HPA axis, and, through tonic regulation of the PVN (Herman et al, 1994; Herman et al, 2002), mediates both the physiological (Choi et al, 2007) and the behavioralaffective response to stress (Cecchi et al, 2002; Davis and Shi, 1999). The aim of the present investigation was to explore the mechanisms mediating the sequalae of behavioral and endocrine phenotypes induced by chronic intermittent psychological stress. Moreover, these experiments are the first to delineate the role of the CRF receptors of the $\mathrm{BNST}_{\mathrm{AL}}$ in modulating anxiety and pain following repeated psychological stress.

\section{The Effects of WAS on the HPA Function}

The psychological and psychosomatic impact of repeated exposure to stress includes deterioration of mental and physiological functions, which can result from failure to habituate to a repetition of the same stressor (McEwen, 1998; McEwen and Gianaros, 2010). In the present study, we confirmed that the F-344 rat strain fails to habituate to stress, as serum CORT and ACTH levels remain high after repeated exposure to WAS, similar to that previously reported (Dhabhar et al, 1997). The potentiated HPA response and subsequent stress-induced psychological and physiological conditions are postulated to be due to hyperexcitability of limbic circuitry (Rosen and Schulkin, 1998), and result from repeated exposure to CRF activation (Rainnie et al, 2004). Interestingly, impairment of the HPA axis in F-344 rats was reported to involve CRF (Sternberg et al, 1992), which is supported by the present findings in the $\mathrm{BNST}_{\mathrm{AL}}$.

\section{The Effect of WAS on CRF Mechanisms in the $\mathrm{BNST}_{\mathrm{AL}}$}

In contrast to the numerous studies implicating the involvement of CRF mechanisms in the amygdala-reviewed by 

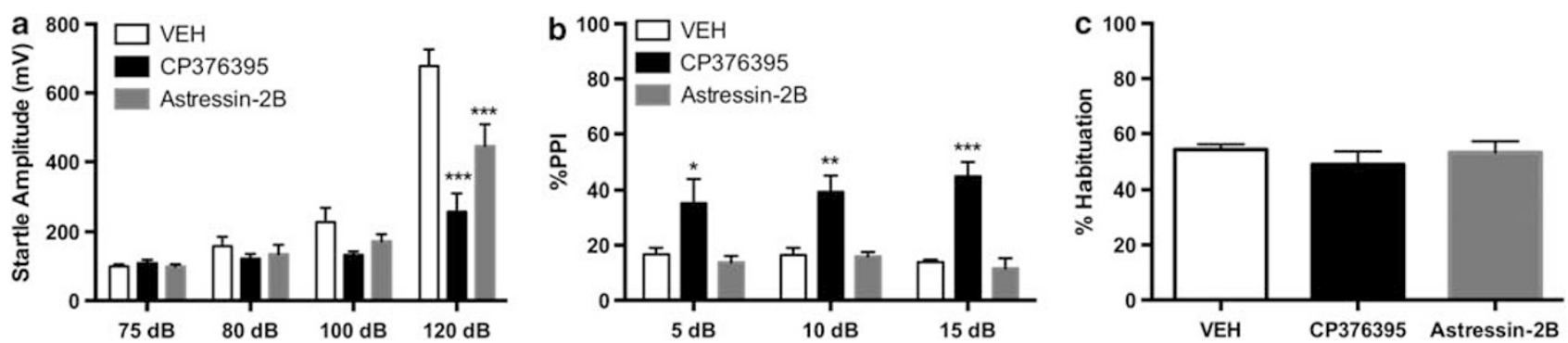

Figure 6 Effect of corticotropin-releasing factor (CRF) receptor antagonists on acoustic startle reflex (ASR) and prepulse inhibition (PPI). Animals were implanted with bilateral cannulas localized to the anteriolateral bed nucleus of the stria terminalis (BNST $\mathrm{AL}$ ) and exposed to the water avoidance stress (WAS) protocol. Before behavioral assessment, the animals received infusions of either vehicle (VEH; normal saline; $n=5)$, the $C R F$, receptor antagonist CP376395 (I0 mg/ml; $n=5)$, or the $\mathrm{CRF}_{2}$ receptor antagonist Astressin ${ }_{2} \mathrm{~B}(\mathrm{I} 00 \mu \mathrm{M} ; n=5)$. Following WAS, animals infused with $C R F_{1}$ receptor antagonists had (a) a decrease in startle amplitude and (b) increased prepulse inhibition compared with animals infused with VEH. Animals infused with $\mathrm{CRF}_{2}$ receptor antagonists also had a decrease in startle amplitude, but to a lesser extent, and no change in prepulse inhibition. (c) Neither treatment had any effect on percent habituation. Data represent mean $\pm \mathrm{SEM}$, $* P<0.05$, $* * P<0.0$ I, and $* * * P<0.00$ I by one-way analysis of variance (ANOVA) or two-way ANOVA with repeated measures (ANOVA-RM) with Bonferonni post hoc analysis.

(Bonaz and Bernstein, 2013; Myers and Greenwood-Van Meerveld, 2007)-less is known about the role of CRF in the BNST. Therefore, in the present study we aimed to investigate the role of the CRF system in the $\mathrm{BNST}_{\mathrm{AL}}$ in precipitating exaggerated anxiety and nociception following chronic intermittent psychological stress. In response to our WAS protocol, we found an increase in CRF mRNA in the $\mathrm{BNST}_{\mathrm{AL}}$ similar to our previous studies and others (Makino et al, 1994; Tran et al, 2012c; Watts and Sanchez-Watts, 1995). These data suggest that much like the amygdala, CRF content in the $\mathrm{BNST}_{\mathrm{AL}}$ facilitates the behavioral responses to a challenge.

In subsequent studies, the importance of CRF expression in the amygdala with regard to the observed behaviors was confirmed using site-specific genetic manipulation of CRF (Regev et al, 2012). However, recent findings using similar CRF overexpression techniques in the BNST suggested that regulation of stress-induced anxiety in this brain region may depend more on the CRF receptors (Sink et al, 2013). Thus, our following experiments focused on delineating the function of the CRF receptors, which were disproportionally upregulated after WAS.

\section{The Function of the CRF Receptors in the $\mathrm{BNST}_{\mathrm{AL}}$ May be Pathway-Dependent}

Chronic stress and CRF dysregulation in the BNST have been linked to many traits commonly associated with the amygdala dysfunction including fear (Walker et al, 2003), anxiety (Ventura-Silva et al, 2012), anhedonia (Stout et al, 2000), addiction (Erb et al, 2001), and the emotional component of visceral and somatic pain (Deyama et al, 2007; Tran et al, 2012c). Our investigation focused primarily on anxiety and pain behaviors induced by a chronic repeated psychological stressor. Using specific $\mathrm{CRF}_{1}$ and $\mathrm{CRF}_{2}$ receptor antagonists, we found circumstantial evidence for both converging and opposing receptor functions, dependent on the behavior under investigation. Although our results support previous reports of CRF receptor function on the anxiety-like behavior in the EPM (Sahuque et al, 2006; Sink et al, 2013) and modulation of somatic pain processing (Ji and Neugebauer, 2008), the observed changes in visceral sensitivity contradicted previous studies using peripherally restricted $\mathrm{CRF}_{1}$ and $\mathrm{CRF}_{2}$ receptor antagonists (Greenwood-Van Meerveld et al, 2005; Nijsen et al, 2005). This suggested that the effects of $\mathrm{CRF}_{1}$ and $\mathrm{CRF}_{2}$ receptor activation, at least on visceral sensitivity, may differ depending on the localization of the receptors.

\section{CRF Modulation of the ASR and PPI Highlights Potential Receptor Configuration}

Although experimental evidence suggests differences in the central processing of somatic and visceral pain, the information outlining the divergence in the pathways is limited (Zhou et al, 2010). However, further studies on the relationship between CRF receptor function and wellestablished pathways may lead to key insights into the pain circuitry. Therefore, we focused our investigation on anxiety-related behaviors, which exhibit both complementary and opposing CRF receptor mechanisms in unconditioned and conditioned paradigms (Lee and Davis, 1997). Specifically, we examined the ASR, which is sensitive to anxiety levels, anatomically well defined, and involves CRF activation in the BNST (Davis et al, 1997). The acoustic startle paradigm is also clinically relevant as it is heightened in patients with IBS (Naliboff et al, 2008), enhanced by abdominal stimuli (Hubbard et al, 2011), and linked to increased activation of the extended amygdala (Naliboff et al, 2006).

In the present study, the effects of $\mathrm{CRF}_{1}$ and $\mathrm{CRF}_{2}$ receptor antagonism on ASR and PPI were not examined at baseline, limiting the interpretation of the effects following WAS to what has been reported in the literature. Those previous studies have suggested increased ASR and attenuation of the PPI following CRF injections (Conti, 2005; Conti et al, 2002). Moreover, when the global roles of $\mathrm{CRF}_{1}$ and $\mathrm{CRF}_{2}$ receptors were investigated, early findings indicated similar functions in facilitating ASR, but opposing effects on the PPI (Risbrough et al, 2004). The data from the present study using specific infusions into the $\mathrm{BNST}_{\mathrm{AL}}$ following WAS support these findings and further indicate that the primary acoustic startle pathway receives complementary input from 
the CRF receptors in the $\mathrm{BNST}_{\mathrm{AL}}$ while the PPI pathway receives opposing input.

\section{Anatomical Model}

Contrasting modulation of different pathways is possible in the $\mathrm{BNST}_{\mathrm{AL}}$ because of the presence of at least three different cell types determined by the different expression patterns of intrinsic membrane currents in the $\mathrm{BNST}_{\mathrm{AL}}$ (Hammack et al, 2007). Evidence suggests that $\mathrm{CRF}_{1}$ and $\mathrm{CRF}_{2}$ receptors are disproportionately distributed on the various cell types in the $\mathrm{BNST}_{\mathrm{AL}}$ (Dabrowska et al, 2011). As the $\mathrm{BNST}_{\mathrm{AL}}$ integrates both excitatory and inhibitory emotional and nociceptive signals from multiple brain regions (Myers et al, 2013; Radley and Sawchenko, 2011), $\mathrm{CRF}_{1}$ and $\mathrm{CRF}_{2}$ receptors can both facilitate and attenuate output behavior depending on the localization of the receptors. For example, Fu and Neugebauer (2008) reported that inhibition of $\mathrm{CRF}_{2}$ receptors with Astressin ${ }_{2} \mathrm{~B}$ facilitates glutamatergic synaptic transmission in the amygdala by inhibiting GABAergic transmission. Although the $\mathrm{BNST}_{\mathrm{AL}}$ is a distinctly different brain region, it similarly comprises a CRF-modulated GABAergic/glutamatergic network, and thus disinhibition following $\mathrm{CRF}_{2}$ receptors antagonism, such as in the present study, was previously predicted by anatomical models because of the distinct localization of $\mathrm{CRF}_{2}$ receptors relative to $\mathrm{CRF}_{1}$ receptors (Dabrowska et al, 2011). Moreover, evidence suggests that the outputs from the $\mathrm{BNST}_{\mathrm{AL}}$, such as to the PVN, are facilitated by activation of $\mathrm{CRF}_{1}$ receptors and inhibited by reciprocal projections to the BNST via $\mathrm{CRF}_{2}$ receptors. The behaviors observed in the present study follow this trend, with the exception of the acoustic startle and visceromotor reflexes. However, to our knowledge, there is no evidence indicating that the acoustic startle or visceral pain afferents relay through the BNST.

Visceral pain signals from the thalamus project to the visceromotor pattern network in the medial PVN and then directly to the NTS (Thompson and Swanson, 2003), whereas acoustic startle information projects to the cochlear nucleus and then to the nucleus reticularis pontis caudalis (PnC; Lee et al, 1996). On the basis of the results from the current study, we postulate that the $\mathrm{BNST}_{\mathrm{AL}}$ may modulate these pathways through afferents to brainstem nuclei, which are facilitated by $\mathrm{CRF}_{2}$ receptors. In support, previous studies have demonstrated that the acoustic startle response is enhanced by fear and anxiety via projections to the $\mathrm{PnC}$ (Koch and Schnitzler, 1997). An interesting caveat to note is that our gene expression data following WAS support the facilitation of both ancillary and diametrical roles of the CRF receptors. In pathways where $\mathrm{CRF}_{1}$ and $\mathrm{CRF}_{2}$ have complementary roles, our experiments show increased expression of both receptors following WAS, resulting in a net excitatory effect. Pathways in which $\mathrm{CRF}_{1}$ and $\mathrm{CRF}_{2}$ have opposing roles on behavior will still have a net excitatory effect on behavior due to the nearly fourfold increase in $\mathrm{CRF}_{1}$ receptors over the twofold increase observed for $\mathrm{CRF}_{2}$ receptors.

In summary, our results indicate that the functional role of $\mathrm{CRF}_{1}$ and $\mathrm{CRF}_{2}$ receptors varies depending upon the physiological or behavioral responses under investigation. Although our findings in the $\mathrm{BNST}_{\mathrm{AL}}$ suggest that the observed effects are likely due to differences in the localization of the CRF receptors, further anatomical studies are necessary in order to provide conclusive evidence. Overall, our results provide substantial insight into the CRF receptor-associated mechanisms that likely underpin stressinduced pathologies such as IBS, and are important when considering CRF as a potential therapeutic target.

\section{FUNDING AND DISCLOSURE}

Funding was provided by the U.S. Department of Veterans Affairs. The authors declare no conflict of interest.

\section{ACKNOWLEDGEMENTS}

BG-VM would like to acknowledge the generous funding support for her Research Career Scientist and Merit Review Awards from the Department of Veterans Affairs.

\section{REFERENCES}

Allen C, Kendall JW (1967). Maturation of the circadian rhythm of plasma corticosterone in the rat. Endocrinology 80: 926-930.

Berman SM, Naliboff BD, Suyenobu B, Labus JS, Stains J, Ohning G et al (2008). Reduced brainstem inhibition during anticipated pelvic visceral pain correlates with enhanced brain response to the visceral stimulus in women with irritable bowel syndrome. J Neurosci 28: 349-359.

Bonaz B, Baciu M, Papillon E, Bost R, Gueddah N, Le Bas JF et al (2002). Central processing of rectal pain in patients with irritable bowel syndrome: an fMRI study. Am J Gastroenterol 97: 654-661.

Bonaz BL, Bernstein CN (2013). Brain-gut interactions in inflammatory bowel disease. Gastroenterology 144: 36-49.

Bradesi S, Schwetz I, Ennes HS, Lamy CM, Ohning G, Fanselow M et al (2005). Repeated exposure to water avoidance stress in rats: a new model for sustained visceral hyperalgesia. Am J Physiol Gastrointest Liver Physiol 289: G42-G53.

Cecchi M, Khoshbouei H, Javors M, Morilak DA (2002). Modulatory effects of norepinephrine in the lateral bed nucleus of the stria terminalis on behavioral and neuroendocrine responses to acute stress. Neuroscience 112: 13-21.

Chang L, Sundaresh S, Elliott J, Anton PA, Baldi P, Licudine A et al (2009). Dysregulation of the hypothalamic-pituitary-adrenal (HPA) axis in irritable bowel syndrome. Neurogastroenterol Motil 21: 149-159.

Chen CY, Inui A, Asakawa A, Fujino K, Kato I, Chen CC et al (2005). Des-acyl ghrelin acts by CRF type 2 receptors to disrupt fasted stomach motility in conscious rats. Gastroenterology 129: 8-25.

Choi DC, Furay AR, Evanson NK, Ostrander MM, Ulrich-Lai YM, Herman JP (2007). Bed nucleus of the stria terminalis subregions differentially regulate hypothalamic-pituitary-adrenal axis activity: implications for the integration of limbic inputs. J Neurosci 27: 2025-2034.

Conti LH (2005). Characterization of the effects of corticotropinreleasing factor on prepulse inhibition of the acoustic startle response in Brown Norway and Wistar-Kyoto rats. Eur $J$ Pharmacol 507: 125-134.

Conti LH, Murry JD, Ruiz MA, Printz MP (2002). Effects of corticotropin-releasing factor on prepulse inhibition of the acoustic startle response in two rat strains. Psychopharmacology (Berl) 161: 296-303.

Dabrowska J, Hazra R, Ahern TH, Guo JD, McDonald AJ, Mascagni $\mathrm{F}$ et al (2011). Neuroanatomical evidence for reciprocal regulation of the corticotrophin-releasing factor and oxytocin systems in the hypothalamus and the bed nucleus of the stria 
terminalis of the rat: Implications for balancing stress and affect. Psychoneuroendocrinology 36: 1312-1326.

Davis M, Shi C (1999). The extended amygdala: are the central nucleus of the amygdala and the bed nucleus of the stria terminalis differentially involved in fear versus anxiety? Ann N Y Acad Sci 877: 281-291.

Davis M, Walker DL, Lee Y (1997). Roles of the amygdala and bed nucleus of the stria terminalis in fear and anxiety measured with the acoustic startle reflex. Possible relevance to PTSD. Ann N Y Acad Sci 821: 305-331.

Deyama S, Nakagawa T, Kaneko S, Uehara T, Minami M (2007). Involvement of the bed nucleus of the stria terminalis in the negative affective component of visceral and somatic pain in rats. Behav Brain Res 176: 367-371.

Dhabhar FS, McEwen BS, Spencer RL (1997). Adaptation to prolonged or repeated stress-comparison between rat strains showing intrinsic differences in reactivity to acute stress. Neuroendocrinology 65: 360-368.

Dinan TG, Quigley EM, Ahmed SM, Scully P, O'Brien S, O'Mahony $\mathrm{L}$ et al (2006). Hypothalamic-pituitary-gut axis dysregulation in irritable bowel syndrome: plasma cytokines as a potential biomarker? Gastroenterology 130: 304-311.

Dong HW, Swanson LW (2004). Organization of axonal projections from the anterolateral area of the bed nuclei of the stria terminalis. J Comp Neurol 468: 277-298.

Erb S, Shaham Y, Stewart J (2001). Stress-induced relapse to drug seeking in the rat: role of the bed nucleus of the stria terminalis and amygdala. Stress 4: 289-303.

Fu Y, Neugebauer V (2008). Differential mechanisms of CRF1 and CRF2 receptor functions in the amygdala in pain-related synaptic facilitation and behavior. J Neurosci 28: 3861-3876.

Fukudo S (2013). Stress and visceral pain: focusing on irritable bowel syndrome. Pain 154(Suppl 1): S63-S70.

Gibney SM, Gosselin RD, Dinan TG, Cryan JF (2010). Colorectal distension-induced prefrontal cortex activation in the WistarKyoto rat: implications for irritable bowel syndrome. Neuroscience 165: 675-683.

Greenwood-Van Meerveld B, Gibson M, Gunter W, Shepard J, Foreman R, Myers D (2001). Stereotaxic delivery of corticosterone to the amygdala modulates colonic sensitivity in rats. Brain Res 893: 135-142.

Greenwood-Van Meerveld B, Johnson AC, Cochrane S, Schulkin J, Myers DA (2005). Corticotropin-releasing factor 1 receptormediated mechanisms inhibit colonic hypersensitivity in rats. Neurogastroenterol Motil 17: 415-422.

Hammack SE, Mania I, Rainnie DG (2007). Differential expression of intrinsic membrane currents in defined cell types of the anterolateral bed nucleus of the stria terminalis. J Neurophysiol 98: 638-656.

Herman JP, Cullinan WE, Watson SJ (1994). Involvement of the bed nucleus of the stria terminalis in tonic regulation of paraventricular hypothalamic CRH and AVP mRNA expression. J Neuroendocrinol 6: 433-442.

Herman JP, Tasker JG, Ziegler DR, Cullinan WE (2002). Local circuit regulation of paraventricular nucleus stress integration: glutamateGABA connections. Pharmacol Biochem Behav 71: 457-468.

Hubbard CS, Ornitz E, Gaspar JX, Smith S, Amin J, Labus JS et al (2011). Modulation of nociceptive and acoustic startle responses to an unpredictable threat in men and women. Pain 152: $1632-1640$.

Ji G, Neugebauer V (2008). Pro- and anti-nociceptive effects of corticotropin-releasing factor (CRF) in central amygdala neurons are mediated through different receptors. J Neurophysiol 99: 1201-1212.

Johnson AC, Tran L, Schulkin J, Greenwood-Van Meerveld B (2012). Importance of stress receptor-mediated mechanisms in the amygdala on visceral pain perception in an intrinsically anxious rat. Neurogastroenterol Motil 24: 479-486.
Koch M, Schnitzler HU (1997). The acoustic startle response in rats-circuits mediating evocation, inhibition and potentiation. Behav Brain Res 89: 35-49.

Lee Y, Davis M (1997). Role of the hippocampus, the bed nucleus of the stria terminalis, and the amygdala in the excitatory effect of corticotropin-releasing hormone on the acoustic startle reflex. J Neurosci 17: 6434-6446.

Lee Y, Lopez DE, Meloni EG, Davis M (1996). A primary acoustic startle pathway: obligatory role of cochlear root neurons and the nucleus reticularis pontis caudalis. J Neurosci 16: 3775-3789.

Makino S, Gold PW, Schulkin J (1994). Corticosterone effects on corticotropin-releasing hormone mRNA in the central nucleus of the amygdala and the parvocellular region of the paraventricular nucleus of the hypothalamus. Brain Res 640: 105-112.

McEwen BS (1998). Protective and damaging effects of stress mediators. N Engl J Med 338: 171-179.

McEwen BS, Gianaros PJ (2010). Central role of the brain in stress and adaptation: links to socioeconomic status, health, and disease. Ann N Y Acad Sci 1186: 190-222.

Myers B, Greenwood-Van Meerveld B (2007). Corticosteroid receptor-mediated mechanisms in the amygdala regulate anxiety and colonic sensitivity. Am J Physiol Gastrointest Liver Physiol 292: G1622-G1629.

Myers B, Greenwood-Van Meerveld B (2010). Elevated corticosterone in the amygdala leads to persistent increases in anxiety-like behavior and pain sensitivity. Behav Brain Res 214: 465-469.

Myers B, Greenwood-Van Meerveld B (2012). Differential involvement of amygdala corticosteroid receptors in visceral hyperalgesia following acute or repeated stress. Am J Physiol Gastrointest Liver Physiol 302: 6260-6266.

Myers B, Mark Dolgas C, Kasckow J, Cullinan WE, Herman JP (2013). Central stress-integrative circuits: forebrain glutamatergic and GABAergic projections to the dorsomedial hypothalamus, medial preoptic area, and bed nucleus of the stria terminalis. Brain Struct Funct (epub ahead of print, doi:10.1007/s00429-013-0566-y).

Myers DA, Gibson M, Schulkin J, Greenwood Van-Meerveld B (2005). Corticosterone implants to the amygdala and type $1 \mathrm{CRH}$ receptor regulation: effects on behavior and colonic sensitivity. Behav Brain Res 161: 39-44.

Naliboff BD, Berman S, Suyenobu B, Labus JS, Chang L, Stains J et al (2006). Longitudinal change in perceptual and brain activation response to visceral stimuli in irritable bowel syndrome patients. Gastroenterology 131: 352-365.

Naliboff BD, Waters AM, Labus JS, Kilpatrick L, Craske MG, Chang $\mathrm{L}$ et al (2008). Increased acoustic startle responses in IBS patients during abdominal and nonabdominal threat. Psychosom Med 70: 920-927.

Nijsen M, Ongenae N, Meulemans A, Coulie B (2005). Divergent role for CRF1 and CRF2 receptors in the modulation of visceral pain. Neurogastroenterol Motil 17: 423-432.

Ohmura Y, Izumi T, Yamaguchi T, Tsutsui-Kimura I, Yoshida T, Yoshioka M (2010). The serotonergic projection from the median raphe nucleus to the ventral hippocampus is involved in the retrieval of fear memory through the corticotropin-releasing factor type 2 receptor. Neuropsychopharmacology 35: 1271-1278.

Radley JJ, Sawchenko PE (2011). A common substrate for prefrontal and hippocampal inhibition of the neuroendocrine stress response. J Neurosci 31: 9683-9695.

Rainnie DG, Bergeron R, Sajdyk TJ, Patil M, Gehlert DR, Shekhar A (2004). Corticotrophin releasing factor-induced synaptic plasticity in the amygdala translates stress into emotional disorders. J Neurosci 24: 3471-3479.

Regev L, Tsoory M, Gil S, Chen A (2012). Site-specific genetic manipulation of amygdala corticotropin-releasing factor reveals its imperative role in mediating behavioral response to challenge. Biol Psychiatry 71: 317-326. 
Risbrough VB, Hauger RL, Roberts AL, Vale WW, Geyer MA (2004). Corticotropin-releasing factor receptors CRF1 and CRF2 exert both additive and opposing influences on defensive startle behavior. J Neurosci 24: 6545-6552.

Rosen JB, Schulkin J (1998). From normal fear to pathological anxiety. Psychol Rev 105: 325-350.

Sahuque LL, Kullberg EF, McGeehan AJ, Kinder JR, Hicks MP, Blanton MG et al (2006). Anxiogenic and aversive effects of corticotropin-releasing factor (CRF) in the bed nucleus of the stria terminalis in the rat: role of CRF receptor subtypes. Psychopharmacology (Berl) 186: 122-132.

Schulkin J, Gold PW, McEwen BS (1998). Induction of corticotropin-releasing hormone gene expression by glucocorticoids: implication for understanding the states of fear and anxiety and allostatic load. Psychoneuroendocrinology 23: 219-243.

Shepard JD, Barron KW, Myers DA (2000). Corticosterone delivery to the amygdala increases corticotropin-releasing factor mRNA in the central amygdaloid nucleus and anxiety-like behavior. Brain Res 861: 288-295.

Shepard JD, Barron KW, Myers DA (2003). Stereotaxic localization of corticosterone to the amygdala enhances hypothalamopituitary-adrenal responses to behavioral stress. Brain Res 963: 203-213.

Sink KS, Walker DL, Freeman SM, Flandreau EI, Ressler KJ, Davis M (2013). Effects of continuously enhanced corticotropin releasing factor expression within the bed nucleus of the stria terminalis on conditioned and unconditioned anxiety. Mol Psychiatry 18: 308-319.

Sternberg EM, Glowa JR, Smith MA, Calogero AE, Listwak SJ, Aksentijevich S et al (1992). Corticotropin releasing hormone related behavioral and neuroendocrine responses to stress in Lewis and Fischer rats. Brain Res 570: 54-60.

Stout SC, Mortas P, Owens MJ, Nemeroff CB, Moreau J (2000). Increased corticotropin-releasing factor concentrations in the bed nucleus of the stria terminalis of anhedonic rats. Eur $J$ Pharmacol 401: 39-46.

Tanaka Y, Morishita J, Kanazawa M, Hamaguchi T, Tashiro M, Fukudo S (2011). Corticotropin-releasing hormone is associated with exaggerated brain activity and pituitary-adrenal response during colorectal distention in men. Gastroenterology 140: S57.

Thompson RH, Swanson LW (2003). Structural characterization of a hypothalamic visceromotor pattern generator network. Brain Res Brain Res Rev 41: 153-202.

Tran L, Chaloner A, Sawalha AH, Greenwood Van-Meerveld B (2013). Importance of epigenetic mechanisms in visceral pain induced by chronic water avoidance stress. Psychoneuroendocrinology 38: 898-906.

Tran L, Greenwood-Van Meerveld B (2012a). Altered expression of glucocorticoid receptor and corticotropin-releasing factor in the central amygdala in response to elevated corticosterone. Behav Brain Res 234: 380-385.

Tran L, Greenwood-Van Meerveld B (2012b). Lateralized amygdala activation: importance in the regulation of anxiety and pain behavior. Physiol Behav 105: 371-375.

Tran L, Wiskur B, Greenwood-Van Meerveld B (2012c). The role of the anteriolateral bed nucleus of the stria terminalis in stressinduced nociception. Am J Physiol Gastrointest Liver Physiol 302: G1301-G1309.

Venkova K, Johnson AC, Myers B, Greenwood-Van Meerveld B (2010). Exposure of the amygdala to elevated levels of corticosterone alters colonic motility in response to acute psychological stress. Neuropharmacology 58: 1161-1167.

Ventura-Silva AP, Pego JM, Sousa JC, Marques AR, Rodrigues AJ, Marques F et al (2012). Stress shifts the response of the bed nucleus of the stria terminalis to an anxiogenic mode. Eur $J$ Neurosci 36: 3396-3406.

Walker DL, Toufexis DJ, Davis M (2003). Role of the bed nucleus of the stria terminalis versus the amygdala in fear, stress, and anxiety. Eur J Pharmacol 463: 199-216.

Watts AG, Sanchez-Watts G (1995). Region-specific regulation of neuropeptide mRNAs in rat limbic forebrain neurones by aldosterone and corticosterone. J Physiol 484(Pt 3): 721-736.

Zhou Q, Fillingim RB, Riley JL 3rd, Malarkey WB, Verne GN (2010). Central and peripheral hypersensitivity in the irritable bowel syndrome. Pain 148: 454-461.

Zorrilla EP, Roberts AJ, Rivier JE, Koob GF (2013). Anxiolytic-like effects of antisauvagine-30 in mice are not mediated by CRF2 receptors. PLoS ONE 8: e63942.

Supplementary Information accompanies the paper on the Neuropsychopharmacology website (http://www.nature.com/npp) 